\title{
PENINGKATAN HAK GUNA BANGUNAN RUMAH TINGGAL DIBEBANI HAK TANGGUNGAN MENJADI HAK MILIK DIATAS HAK PENGELOLAAN*
}

\author{
Aflinda Dewi \\ Fakultas Hukum Magister Kenotariatan Universitas Andalas, Komplek Taruko Permai IV, \\ Blok L Nomor 23, RT 002, RW 013, Kel. Bungo Pasang, Kec. Koto Tangah, Kota Padang. \\ e-mail: 09aflinda75@gmail.com
}

\begin{abstract}
The time period given to Building Utilization Rights for houses and used as collateral for debts by the Debtor, will cause legal problems in the future, the debtor does not have legal certainty regarding his rights, and for Creditors it will be difficult to sell in the event of bad credit. Debtor based on PerMenAg / Ka. The Land Agency Number 5 of 1998, can apply for an increase in ownership rights without paying off the debt first. Requests for increased rights can be processed after the Debtor has received written approval from the Creditors. For the continuity of credit guarantee prior to HM Upgrade, SKMHT is made. This article is based on the implementation of the Increased Right to Use for Residential Buildings which are burdened with Underwriting rights to Ownership Rights at the Land Office of Padang City by using the Empirical Juridical Method, where the author conducts research directly into the Padang City land office. Conclusion of the implementation of increasing use rights of residential buildings which are burdened with mortgage rights at the Land Office based on the Minister of Religion / Head of BPB No. 5 of 1998, carried out according to the procedure, does not take a long time and costs a lot.
\end{abstract}

Keywords: Building Use Rights; Residential Houses; Approval Letter.

\begin{abstract}
Abstrak
Jangka Waktu yang diberikan kepada Hak Guna Bangunan untuk rumah tinggal dan dijadikan jaminan utang oleh Debitur, akan menimbulkan permasalahan hukum di kemudian hari, debitur tidak mempunyai kepastian hukum terhadap haknya, dan bagi Kreditur akan sulit melakukan penjualan apabila terjadi kredit macet. Debitur berdasarkan PerMenAg/Ka. Badan Pertanahan Nomor 5 Tahun 1998, dapat mengajukan permohonan peningkatan (Hak Guna Bangunan) menjadi Hak Milik (HM) tanpa melunasi utangnya terlebih dahulu. Permohonan peningkatan hak dapat diproses setelah Debitur mendapat persetujuan tertulis dari Kreditur. Untuk kelangsungan jaminan kredit sebelum Peningkatan HM, dibuatkan SKMHT. Artikel ini berdasarkan pelaksanaan Peningkatan Hak Guna Bangunan rumah tinggal yang dibebani hak Tanggungan menjadi Hak Milik pada Kantor Pertanahan Kota Padang dengan menggunakan metode Yuridis Empiris, dimana penulis melakukan penelitian langsung ke kantor pertanahan Kota Padang. Kesimpulan pelaksanaan peningkatan Hak Guna Bangunan rumah tinggal yang dibebani Hak Tanggungan pada Kantor Pertanahan berdasarkan PerMenag/Kepala BPB no.5 tahun 1998, dilaksanakan sesuai prosedur, tidak memakan waktu yang lama dan biaya yang besar.
\end{abstract}

Kata Kunci : Hak Guna Bangunan; Rumah tinggal; Surat Persetujuan

\footnotetext{
* Naskah diterima: 25 Juli 2019, direvisi: 15 Agustus 2019, disetujui untuk terbit: 30 September 2019

Doi: $10.3376 /$ jch.v5i1.174
} 
Aflinda Dewi: Peningkatan Hak Guna Bangunan Rumah Tinggal Dibebani Hak...

\section{PENDAHULUAN}

Setiap keluarga mempunyai impian untuk mempunyai rumah, rumah tempat berteduh, tempat memberikan pendidikan kepada anak-anak dan tempat beristirahat. Berbagai cara dilakukan oleh orang untuk mendapatkan sebuah rumah, bagi yang mampu dapat membangun dengan dana sendiri, bagi masyarakat berpenghasilan

menengah kebawah, memanfaatkan pembelian rumah dengan secara kredit, melalui fasilitas pembiayaan oleh Perbankan dengan jenis kredit Pemilikan

Rumah (KPR). Perumahan yang difasilitasi KPR rata-rata dibangun oleh Pengembang atau Developer yang berbadan Hukum. Tanah yang dibangun oleh Pengembang yang berbadan hukum, kepadanya diberikan dengan status Hak Guna Bangunan dengan jangka waktu 30 tahun sertipikat induk, berlaku sama terhadap sertipikat pecahannya untuk kepentingan pengkaplingan. Status Hak Guna Bangunan tetap melekat pada Sertifikat(sertipikat) pecahan meskipun sudah beralih haknya ke atas nama Pembeli. Pada prakteknya dengan pertimbangan lain, pemberian Jangka waktu Hak Guna Bangunan oleh kepala Kantor Pertanahan kepada Perseroan Terbatas ditemui ada hanya 20 (duapuluh) tahun.

Masyarakat harus mengetahui tentang Pentingnya Peningkatan Hak Guna Bangunan Menjadi Hak Milik rumah tinggal yang dimiliknya, melalui penyuluhan-penyuluhan dari Pihak Badan Pertanahan setempat. (WD Sukirno, 2004)
Pembelian rumah tinggal dengan status Hak Guna Bangunan (HGB)

melalui KPR perbankan dengan menjadikan tanah dan bangunan yang dibelinya sebagai Jaminan utang oleh pemegang Hak yang akan dibebani Hak Tanggungan, yang didahului dengan Perjanjian Kredit, pembebanan Hak Tanggungan diatur dalam Pasal 39

Undang-Undang Pokok Agraria (Selanjutnya disebut UUPA) jo pasal 33

PP Nomor 40 tahun 1996 (Urip Santoso; 2012). Pembebanan Hak Tanggungan terhadap HGB yang haknya dibatasi jangka waktu, menimbulkan berbagai permasalahan hukum, baik bagi pemegang Hak maupun Pemegang Hak Tanggungan. Seperti kasus hukum yang terjadi terhadap Sertipikat HGB Nomor 60../Kelurahan Bungo Pasang, Kota Padang, dimana Pemegang Hak membeli sebuah rumah melalui kredit KPR di Bank Konvensional yang berkantor Cabang di Kota Padang, dalam kredit berjalan, pemegang Hak atau Debitur meninggal dunia, di saat ahli waris akan melunasi dan mengambil sertipikatnya pada pihak Bank, ternyata jangka waktu HGB sudah berakhir. Berakhirnya jangka waktu HGB dan meninggalnya pemegang Hak, tanah tersebut akan kembali menjadi status tanah Negara. Dan untuk mendapatkan Haknya kembali ahli waris harus mengajukan permohonan pemberian Hak Baru ke kantor Pertanahan Kota Padang, yang prosedur dan tatacara serta persyaratannya sesuai dengan Peraturan Menteri Negara Agraria/Ka.BPN. 
Dengan melampirkan surat Pernyataan pemilikan tanah oleh para ahli waris, surat keterangan lurah setempat, jika permohonan di setujui akan dilakukan pengukuran ulang kelapangan oleh petugas ukur, layaknya mengurus sertipikat baru atas tanah, yang memakan waktu panjang dan biaya yang banyak. Contoh kasus diatas adalah salah satu akibat dijadikannya Hak Guna Bangunan sebagai Jaminan utang. Bagi Pihak Kreditur berakhirnya jangka waktu HGB akan kembali menjadi tanah Negara dan secara langsung pula Hak Tanggungan yang membebaninya, konsekuensi hapusnya Hak Tanggungan maka sebagai pemegang Hak Tanggungan/kreditor hanya sebagai kreditor konkuren dan tidak lagi sebagai kreditor Preferen sehingga piutangnya tidak lagi mendapat perlindungan hukum dari Hak Tanggungan. (Urip Santoso, 2012)

Untuk mencegah terjadinya permasalahan hukum diatas akibat dijadikan Hak Guna Bangunan sebagai Jaminan Kredit, Pemerintah melalui PerMeNag/Kepala Badan Pertanahan Nasional (PMNA/KBPN) Nomor 5 tahun 1998 tentang Perubahan Hak Guna Bangunan atau Hak Pakai atas Tanah untuk Rumah Tinggal yang dibebani Hak Tanggungan Menjadi Hak Milik. HGB sedang dibebani Hak Tanggungan dapat dimohonkan peningkatan Hak Milik pada Kantor Pertanahan setempat, tanpa melunasi kreditnya terlebih dahulu,

dengan mengajukan permohonan persetujuan secara tertulis kepada kreditor disertai penyerahan sertipikat Hak Tanggungan kepada Kantor Pertanahan.

Pelaksanaan Peningkatan Hak Guna Bangunan rumah tinggal dibebani Hak Tanggungan menjadi Hak Milik pada Kantor Pertanahan setempat, diproses sesuai dengan prosedur yang diatur dalam Peraturan Menteri Negara Agraria/Kepala Badan Pertanahan Nasional (PMNA/KBPN) Nomor 5 tahun 1998.

Tulisan ini berdasarkan penelitian pada Kantor Pertanahan Kota Padang, mengingat Kota Padang sebagai pusat ibukota Sumatera Barat, yang saat ini pembangunan perumahan untuk rumah tinggal oleh Badan Hukum yang bergerak di bidang Developer/Pengembang sangat pesat perkembangannya, dengan rata-rata tanahnya berstatus Hak Guna Bangunan yang berasal dari Hak Milik.

\section{METODE PENELITIAN}

Metode yang digunakan dalam penelitian ini metode yuridis empiris, merupakan cara prosedur yang digunakan untuk memecahkan masalah dalam

penelitian, dengan mendahulukan penelitian data sekunder, dan untuk memperoleh data primer penelitian dilakukan secara langsung dilapangan.

Pengkajian peraturan perundangundangan dan bahan-bahan pustaka lainnya dengan tujuan mencari kaedah, norma atau das sollen dan perilaku dalam arti sebenarnya atau das sein yang disebut juga pendekatan dengan metode pendekatan yuridis empiris, penggunaan metode ini untuk mengetahui sejauh mana pelaksanaan tentang perubahan Hak Guna Bangunan untuk rumah tinggal yang 
Aflinda Dewi: Peningkatan Hak Guna Bangunan Rumah Tinggal Dibebani Hak...

dibebani Hak Tanggungan menjadi Hak Milik dalam upaya kepastian hukum.

\section{HASIL DAN PEMBAHASAN}

\section{Dasar Hukum Pelaksanaan Peningkatan Hak Guna Bangunan untuk rumah tinggal yang dibebani Hak Tanggungan menjadi Hak Milik}

Hak Guna Bangunan yang berasal atas tanah Negara, Hak Guna Bangunan atas Hak Pengelolaan maupun Hak Guna Bangunan atau Hak Milik untuk rumah tinggal yang sedang dibebani Hak Tanggungan, pemegang haknya dapat mengajukan permohonan peningkatan Hak Milik kepada Kantor pertanahan setempat, dengan persetujuan pemegang Hak Tanggungan, yang proses dan tatacara pelaksanaannya berdasarkan

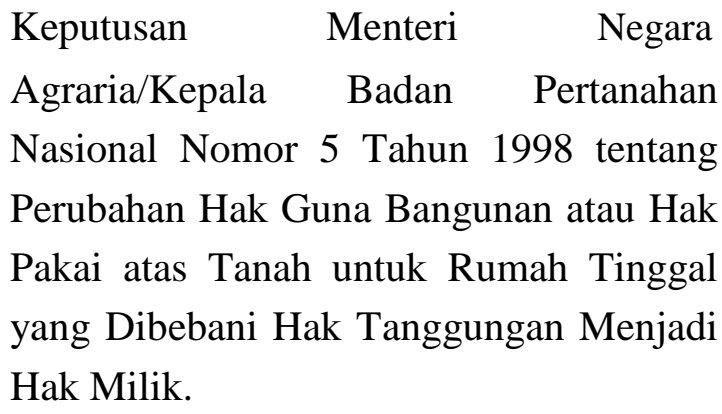

Dalam peraturan ini dijelaskan secara tegas ketentuan hukum dan prosedur pelaksanaan perubahan Hak Guna Bangunan yang sedang dibebani Hak Tanggungan menjadi Hak Milik, dan pelaksanaan harus sesuai dengan Peraturan nomor 5 tahun 1998, karena dengan berubahnya Hak Guna Bangunan yang sedang terbebani Hak Tanggungan menjadi Hak Milik maka Hak Tanggungan yang membebaninya hapus dan gugur dengan sendirinya.
Perubahan Hak Menurut ketentuan Pasal 1 Peraturan Kepala Badan Pertanahan Nasional Nomor 5 Tahun 1998 tersebut adalah (H.M Arba dkk; 2016) :

1. Perubahan Hak adalah penetapan Pemerintah yang menegaskan bahwa sebidang tanah yang semula dipunyai dengan sesuatu hak atas tanah tertentu, atas permohonan pemegang haknya, menjadi tanah Negara dan sekaligus memberikan tanah terebut kepadanya dengan hak atas tanah baru yang lain jenisnya ;

2. Perubahan Hak Guna Bangunan atau Hak Pakai atas tanah untuk rumah tinggal menjadi Hak Milik, adalah Perubahan Hak Guna Bangunan atau Hak Pakai menjadi Hak Milik yang ditetapkan oleh Pemerintah.

Perubahan Hak Guna Bangunan Rumah Tinggal menjadi Hak Milik merupakan peningkatan status tanah dari yang kuat menjadi paling kuat, maka Pelaksanaan perubahan Hak Guna Bangunan atau Hak Pakai untuk rumah tinggal menjadi Hak Milik lebih tepat menggunakan kata Peningkatan Hak Guna Bangunan untuk rumah tinggal menjadi Hak Milik. Peningkatan Hak Guna Bangunan Untuk Rumah Tinggal yang dibebani Hak Tanggungan menjadi Hak Milik berdasarkan pasal 1 ayat (2) Peraturan Menteri Negara Agraria/Kepala Badan Pertanahan Nasional Nomor 5 Tahun 1998, ditetapkan dengan (Tommy Surya Atmaja; 2014) :

a. Keputusan Menteri Negara Agraria/Kepala Badan Pertanahan 
Nasional Nomor 9 Tahun 1997, tentang Pemberian Hak Milik atas tanah untuk rumah tinggal sangat sederhana (RSS) dan rumah sederhana (RS) jo Nomor 15 Tahun 1997 dan Nomor 1 Tahun 1998.

b. Keputusan Menteri Negara Agraria/Kepala Badan Pertanahan Nasional Nomor 2 Tahun 1998, tentang Pemberian Hak Milik atas tanah untuk rumah tinggal yang telah dibeli oleh Pegawai Negeri dari Pemerintah.

c. Keputusan Menteri Negara Agraria/Kepala Badan Pertanahan Nasional Nomor 6 Tahun 1998, tentang Pemberian Hak Milik atas tanah untuk rumah tinggal (Keputusan ini juga sebagai dasar hukum pemberian Hak prioritas untuk lebih diutamakan dalam memperoleh kembali HGB yang belum habis dan/atau telah habis jangka waktunya (Rachasetia Isneni Hakim dkk: 2008).

Atas dasar ketiga Keputusan Menteri Negara Agraria/Kepala Badan Pertanahan Nasional diatas dari hasil penelitian di lapangan dapat disimpulkan, bahwa Peningkatan Hak Guna Bangunan untuk rumah tinggal menjadi Hak Milik yang dibebani Hak Tanggungan dalam Penelitian ini, termasuk dalam pemberian Hak Milik atas tanah Untuk Rumah tinggal dan pemberian Hak Milik untuk rumah RSS dan RS dan yang kategori luas tanahnya telah ditentukan, sebagaimana yang dimaksud dalam Surat Edaran Menteri Negara Agraria Nomor 500-3460 tahun 1998) tentang Petunjuk
Lebih Lanjut Mengenai Pelaksanaan Pemberian Hak Milik dengan Rumah Tinggal, angka 4. Yang menjadi objek pemberian Hak Milik atas tanah untuk rumah tinggal yang dimaksud adalah rumah tinggal:

a. Tanah untuk RSS/RS yang dibangun secaramassal(kompleks)

misalnya Perumahan Umum Nasional (Perumnas) yang dibangun

oleh PT.PERUMNAS yang berkedudukan di Jakarta, yang semula tanahnya diberikan Hak Pengelolaan, dibangun dengan Type RSS/RS 36/96 itu yang artinya luas bangunan $36 \mathrm{~m} 2$ yang dibangun diatas tanah dengan luas $96 \mathrm{~m} 2$ (misalnya Perumahan) di Kota Padang, yang dikenal dengan Perumnas Belimbing terletak di

Kelurahan Kuranji, Kecamatan Kuranji, Kota Padang. Dan Perumahan Komplek yang dibangun oleh perusahaan swasta yang bergerak di bidang Perumahan/Developer, misalnya perumahan Nuansa Griya yang terletak di Kelurahan Kampung Jua, Kecamatan Lubuk Begalung, Kota Padang dan terhadap perumahanperumahan yang berbentuk Komplek lainnya yang di bangunan di wilayah letak tanah manapun dalam wilayah Republik Indonesia.

b. Tanah untuk rumah tinggal yang telah dibeli oleh Pegawai Negeri dari Pemerintah, misalnya rumah dinas yang dihuni oleh Pegawai Negeri Golongan III, yang kemudian dibeli 
Aflinda Dewi: Peningkatan Hak Guna Bangunan Rumah Tinggal Dibebani Hak...

oleh Pegawai Negeri itu kepada Pemerintah, contoh rumah Dinas Departemen Agama di Padang Baru, Kota Padang.

c. Tanah dengan Hak Guna Bangunan untuk rumah tinggal kepunyaan Warga Negara Indonesia, yang luasnya $600 \mathrm{~m} 2$ atau kurang, yang pemberian Hak Milik diatur dalam Peraturan menteri Agraria Nomor 6 tahun 1998.

2. Tata cara Pelaksanaan Permohonan Peningkatan Hak Guna Bangunan atas Tanah untuk Rumah Tinggal yang dibebani Hak Tanggungan menjadi Hak Milik diatas Hak Pengelolaan

Prosedur Pelaksanaan permohonan peningkatan Hak Guna Bangunan atas tanah untuk rumah tinggal yang dibebani Hak Tanggungan menjadi Hak Milik diatas Hak Pengelolaan, dapat dijelaskan sebagai berikut (Hendri Budiyanto dkk; 2015) :

a. Pemegang hak (Debitur) mengajukan Surat permohonan secara tertulis kepada Kreditur selaku pemegang Hak Tanggungan, untuk diberikan izin dan persetujuan kepada debitur melakukan atau mengajukan peningkatan Hak Guna bangunan menjadi Hak Milik terhadap hak tanah yang dijadikan jaminan kredit Pemohon/debitur.Dalamsurat permohonannya debitur mencantumkan alasan kenapa debitur mengajukan peningkatan Hak Guna Bangunan menjadi Hak milik terhadap Jaminan kredit yang sedang berjalan. Surat persetujuan dari Kreditur itu berlaku sebagai persetujuan pelepasan Hak Guna Bangunan menjadi hak Milik

(Peraturan Menteri Negara Agraria/Kepala BPN Nomor 5 tahun 1998 Pasal 2 angka 4.

b. Untuk menghindari kekosongan Jaminan selama proses Peningkatan Hak Guna Bangunan untuk rumah tinggal yang sedang dibebani Hak Tanggungan menjadi Hak Milik, Debitur memberikan Surat Kuasa Membebankan Hak Tanggungan (SKMHT) kepada kreditur yang dibuat di hadapan Pejabat Pembuat

Akta Tanah (PPAT). Syarat Pemberian SKMHT oleh Debitur sebagaimana diatur dalam UndangUndang Nomor 4 tahun 1996 pasal

15. Debitur secara bersama-sama dengan kreditur datang kepada Notaris atau Pejabat Pembuat Akta Tanah, untuk meminta dibuatkan Surat Kuasa Membebankan Hak Tanggungan (SKMHT) terhadap tanah Hak Guna Bangunan yang akan di ajukan Peningkatan Hak milik oleh Debitur. Dalam prakteknya, Notaris atau PPAT yang diminta untuk membuatkan SKMHT itu adalah Notaris/PPAT yang sudah menjadi rekanan Bank atau Kreditur, atau Notaris/PPAT yang sebelumnya membuat Akta Pemberian Hak Tanggungan terhadap Tanah Hak Guna Bangunan yang akan diajukan peningkatan Hak Milik yang dimaksud. Namun debitur dan kreditur dapat juga meminta 
membuatkan SKMHT pada Notaris/PPAT lain, dalam wilayah kerja dimana tanah yang akan dimohonkan Peningkatan Haknya berada. SKMHT yang dibuat sebanyak 2 (dua) lembar oleh Notaris/PPAT oleh debitur dan kreditur, lembar Pertama disimpan sebagai Minuta oleh Notaris/PPAT yang membuatnya, lembar Kedua diberikan kepada Kreditor, yang nantinya dapat digunakan sebagai

dasar Pemberian Akta Hak Tanggungan atas tanah Hak Guna Bangunan yang telah ditingkatkan menjadi Hak Milik di hadapan Pejabat Pembuat Akta Tanah. Jadi dengan adanya SKMHT yang dibuat sebelum permohonan Peningkatan Hak diajukan, kreditur tidak akan merasa kuatir kehilangan hak jaminan dengan berubahnya Hak Guna Bangunan menjadi Hak Milik.

c. Untuk kelangsungan keamanan hak sebagai jaminan kredit, pemegang hak atau debitur memberikan Surat Kuasa Subsitusi kepada Pejabat Pembuat Akta Tanah (Setya ningsih, Anis Mashddurohatun; 2018) yang di tunjuk oleh pihak kreditur untuk mengajukan permohonan Peningkatan Hak Guna Bangunan untuk Rumah tinggal yang sedang terpasang Hak Tanggungan menjadi Hak Milik yang dimaksud, pemegang Hak atau Debitur, memberikan Surat Kuasa kepada PPAT atau petugasnya untuk mengurus peningkatan Hak Guna Bangunan untuk rumah tinggal yang dibebani Hak Tanggungan menjadi Hak milik kepada Kantor Pertanahan, surat kuasa yang dimaksud ditandatangani oleh Pemegang Hak atau Debitur diatas Materai 6000. Sebagai penerima kuasa Debitur, kreditur menyerahkan surat persetujuan sebagaimana dalam poin 1 diatas, disertai sertipikat tanah Hak Guna Bangunan yang sedang terpasang Hak Tanggungan, sertipika) Hak Tanggungan kepada PPAT yang menerima kuasa.

Pejabat Pembuat Akta Tanah (PPAT) melalui petugasnya yang berdasarkan Surat Kuasa dari debitur, mengajukan permohonan Peningkatan Hak Guna Bangunan untuk rumah tinggal menjadi Hak milik yang dibebani Hak Tanggungan kepada Kepala Kantor Pertanahan kota Padang.

Proses Peningkatan Hak Guna Bangunan untuk rumah tinggal yang dibebani Hak Tanggungan menjadi Hak milik pada Kantor Pertanahan, dilaksanakan sesuai dengan SP (Standar Pelayanan dan Pengaturan Pertanahan) yang diatur dalam Peraturan Kepala Badan Pertanahan Nasional Nomor I tahun 2010 dalam lampiran II angka II Nomor 8, dengan tahapan :

a. PPAT selaku kuasa Debitor melalui petugasnya mengajukan permohonan kepada Kepala Kantor Pertanahan Kota Padang, dan mengisi formulir permohonan yang telah disediakan untuk itu, permohonan yang diajukan disertai lampiran:

1) Sertipikat Hak Guna Bangunan yang akan di 
Aflinda Dewi: Peningkatan Hak Guna Bangunan Rumah Tinggal Dibebani Hak...

mohonkan peningkatan hak

milik;

2) Sertipikat Hak Tanggungan yang membebani Hak Guna Bangunan;

3) Surat Persetujuan dari Pemegang Hak Tanggungan mengenai persetujuan perubahan hak yang berlaku sebagaipersetujuan

pelepasan Hak Guna

Bangunan (PerMeNag/K.a BPN No.5 th 1998 psl 2 (4)

4) Fotocopy Akta Jualbeli, sebagai bukti perolehan oleh Pemegang Hak.

5) Fotocopy Izin mendirikan Bangunan (IMB), yang didalamnya tertera, bahwa bangunan yang akan dirikan digunakan untuk rumah tinggal.

6) Fotocopy KTP, Kartu Keluarga Pemegang Hak dan Kuasanya.

7) Fotocopy SPPT PBB tahun berjalan;

8) SuratPernyataandari pemegang Hak bahwa dengan perolehan Hak Milik yang dimohon pendaftarannya itu, yang bersangkutan tidak akan mempunyai hak milik atas tanah-tanah lainnya untuk rumah tinggal yang lebih dari 5 (lima) bidang yang luas keseluruhannya tidak lebih dari 5.000 M2.

9) Surat Kuasa dari Pemegang Hak /pemohon kepada PPAT, untukmengajukan

permohonan peningkatan Hak Guna Bangunan menjadi Hak Milik, terkait dengan Hak sedang dibebani Hak Tanggungan.

b. Setelah permohonan dinyatakan lengkap oleh petugas loket Kantor pertanahan, pemohon membayar Penerimaan Negara Bukan Pajak (PNBP) untuk peningkatan Hak Guna Bangunan menjadi Hak Milik, yang tarifnya sudah ditetapkan berdasarkan Peraturan Pemerintah Nomor 13 Tahun 2010, yakni sebesar Rp.50.000.(lima puluh ribu rupiah).

\section{Proses Hapusnya Hak Tanggungan} atas Hak Guna Bangunan yang diubah menjadi Hak Milik

1) Tatacara cara pelaksanaan Hapusnya Hak Tanggungan Atas Hak Guna Bangunan yang akan diubah menjadi Hak Milik.

Peningkatan Hak Guna Bangunan untuk rumah tinggal yang dibebani Hak Tanggungan menjadi Hak Milik merupakan penegasan mengenai hapusnya atas tanah semula dan pemberian atas tanah yang baru (Ade Fitriawan Sayuti: 2012). Pemberian hak baru mengakibatkan hapusnya Hak Tanggungan yang membebani Hak Guna Bangunan, namun penghapusan Hak Tanggungan itu harus melalui proses dan tetap dilakukan pendaftaran penghapusannya pada Kantor Pertanahan. Kepala Kantor Pertanahan mendaftarkan hapusnya Hak Tanggungan yang membebani Hak Guna Bangunan atau Hak Pakai yang diubah menjadi Hak Milik karena jabatannya bersamaan dengan pendaftaran Perubahan Hak Guna Bangunan Menjadi Hak Milik (PerMenAg/K.a No.5 th 1998 Psl 2 ayat 5), dengan disertakan lampiran-lampiran untuk perubahan Hak Guna Bangunan menjadi Hak Milik sekaligus Pendaftaran Hapusnya Hak Tanggungan. 
Tahap Penghapusan Hak Tanggungan atas Hak Guna Bangunan yang akan diubah menjadi Hak Milik.

Proses penghapusan Hak Tanggungan terhadap tanah dengan Hak Guna Bangunan yang dibebani Hak Tanggungan menjadi Hak Milik, dilakukan dengan tahapan:

a. Pendaftaran penghapusan Hak Tanggungan yang membebankan Hak Guna Bangunan, didaftarkan bersamaan peningkatan Hak Guna Bangunan menjadi Hak Milik, PPAT selaku penerima kuasa dari Debitur mengajukan permohonan kepada Kepala Kantor Pertanahan Kota Padang, dengan mengisi formulir permohonan yang telah disediakan untuk itu disertai dengan melampirkan:

1) Sertipikat Hak Guna Bangunan yang akan di mohonkan peningkatan Hak milik;

2) Sertipikat Hak Tanggungan yang membebani Hak Guna Bangunan;

3) Surat Persetujuan dari Pemegang Hak Tanggungan mengenai persetujuan peningkatan Hak Guna Bangunan menjadi Hak Milik yang berlaku sebagai persetujuan pelepasan Hak Guna Bangunan (PerMenAg/K.a No.5 tahun 1998 Pasal 2 ayat (4);

4) Fotocopy KTP, Kartu Keluarga Pemegang Hak dan Kuasanya.

5) Fotocopy SPPT PBB tahun berjalan;

a. MembayarPenerimaanNegara BukanPajak(PNBP)untuk pendaftaranPenghapusanHak
Tanggungan yang membebani Hak Guna Bangunan, yang tarifnya sudah ditetapkan berdasarkan Peraturan Pemerintah Nomor 13 Tahun 2010, yakni sebesar Rp.50.000.- (lima puluh ribu rupiah).

Kepala Kantor Pertanahan setempat mendaftarkan hapusnya Hak Tanggungan yang membebani Hak Guna Bangunan atau Hak Pakai yang diubah menjadi Hak Milik karena Jabatannya bersamaan dengan pendaftaran Peningkatan Hak Guna Bangunan menjadi Hak Milik yang bersangkutan, artinya dengan kewenangan yang di miliki oleh kepala Kantor Pertanahan setempat, untuk keperluan Peningkatan Hak Guna Bangunan rumah tinggal yang dibebani Hak Tanggungan menjadi Hak milik berdasarkan Peraturan Menteri Agraria/Kepala Badan Pertanahan Nasional Nomor 5 tahun 1998, maka Hak Tanggungan yang membebani Hak Guna Bangunan dihapus.

Kepala Kantor Pertanahan Kota Padang menghapus Hak Tanggungan yang membebani Hak Guna Bangunan karena Jabatannya tidak memerlukan surat permohonan atau surat persetujuan khusus dalam bentuk persetujuan roya atau sejenisnya, karena langkah penghapusan Hak Tanggungan yang membebani Hak Guna Bangunan yang akan dirobah menjadi Hak Milik, telah sesuai dengan ketentuan Pasal 122 ayat (4) jo ayat (6) Peraturan Menteri Negara Agraria/Kepala Badan Pertanahan Nasional Nomor 3 tahun 1997.

Penghapusan Hak Tanggungan yang membebani Hak Guna Bangunan dihapus dan dicatat secara bersamaan oleh Petugas 
Aflinda Dewi: Peningkatan Hak Guna Bangunan Rumah Tinggal Dibebani Hak...

Pengolahan Data pada Buku tanah dan sertifikat Hak yang akan dilakukan perubahan, dasar hukum penghapusan

Hak Tanggungan (Roya) yang membebani Hak Guna Bangunan ditulis dalam buku tanah dan sertipikat Hak guna bangunan yang bunyinya:

"Berdasarkan Peraturan Menteri Agraria/Kepala Badan Pertanahan Nasional Nomor 5 tahun 1998 Pasal 2 dan Surat dari PT. Bank (Persero)tbk, Nomor....tanggal ...... HT No : ...... ini Hapus."

Pencatatan kalimat tersebut juga di tulis pada halaman belakang Sertipikat Hak Tanggungan yang membebani Hak Guna Bangunan, dan selanjutnya Hak Tanggungan yang membebani Hak Guna Bangunan hapus dan Sertipikat Hak Tanggungan ditarik kembali oleh pihak Kantor Pertanahan untuk di simpan di warkah permohonan.

Pencatatan Peningkatan Hak Guna Bangunan menjadi Hak Milik dicetak/ditulis dengan bentuk stempel dengan tinta merah setelah penulisan penghapusan Hak Tanggungan (Roya) pada buku tanah dan Sertifikat hak, yang bunyinya antara lain :

"Dengan Keputusan Menteri Negara Agraria/Kepala Badan Pertanahan

Nasional Nomor Hak Guna Bangunan Nomor : Hapus Dan Diubah menjadi Hak Milik Nomor

3. Proses pembebanan Hak Tanggungan atas Hak Guna Bangunan yang telah berubah menjadi Hak Milik.

1) Tata cara pelaksanaan Pembebanan Hak Tanggungan atas Hak Guna
Bangunan yang telah berubah

menjadi Hak Milik

Hapusnya Hak Tanggungan yang membebani Hak Guna Bangunan yang didaftarkan secara bersamaan dengan Peningkatan Hak, tidak membuat berakhirnya perjanjian kredit. Perjanjian Kredit merupakan Perjanjian pokok yaitu perjanjian yang menimbulkan hubungan hukum utang piutang yang dijamin

pelunasannya, sedangkan Hak Tanggungan menurut sifatnya merupakan ikutan atau Accesoir pada suatu piutang tertentu atau Perjanjian Pokok yang dibuat sebelum Hak Tanggungan

(Penjelasan Undang-Undang Hak Tanggungan No 4 tahun 1996 pasal 10 ayat (1)

Untuk kelangsungan Hutang Piutang dengan jaminan Hak Guna Bangunan sebelumnya, Pejabat Pembuat Akta Tanah (PPAT) dalam menjalankan tugasnya

melaksanakan pendaftaran tanah sebagaimana diatur dalam Pasal 2 Peraturan Pemerintah Nomor 37 tahun 1998, tugas PPAT dalam melaksanakan suatu Recording of deed conveyen yaitu suatu perekaman pembuatan akta tanah yang meliputi mutasi hak, pengikatan jaminan dengan hak atas tanah dengan Hak Tanggungan, mendirikan hak baru diatas sebidang tanah (HGB dan HM atau Hak Pakai diatas Hak MILIK ditambah SKMHT (A.P.Parlindungan:1999), berdasarkan Surat Kuasa Membebankan Hak Tanggungan (SKMHT) lembar kedua yang dibuat sebelum peningkatan Hak Guna Bangunan menjadi Hak Milik, dapat dipergunakan oleh kreditur untuk meminta pembuatan Akta Pemberian Hak 
Tanggungan kepada Pejabat Pembuat Akta Tanah atas sertipikat Hak Milik hasil Peningkatan Hak Guna Bangunan. Pembuatan Akta Pemberian Hak Tanggungan, pemberi dan penerima Hak Tanggungan wajib hadir dihadapan Pejabat Pembuat Akta Tanah (PPAT).

Dalam hal kreditur telah mendapat akta SKMHT dari Debitur sebelum peningkatan Hak Guna Bangunan untuk rumah tinggal yang dibebani Hak Tanggungan menjadi Hak Milik, cukup kreditur saja yang datang ke PPAT untuk meminta dibuatkan Akta Pemberian Hak Tanggungan terhadap Sertipikat Hak

Milik hasil peningkatan Hak Guna Bangunan. Pembuatan Akta Pemberian Hak Tanggungan berdasarkan SKMHT wajib di ikuti dengan Pembuatan akta Pemberian Hak Tanggungan dalam jangka waktu yang telah ditentukan yaitu selambat-lambatnya 1 (satu) bulan sesudah diberikan (pasal 15 angka (3) UUHT nomor 4 tahun 1996.

2) Pembebanan Hak Tanggungan atas Hak Guna Bangunan yang telah berubah menjadi Hak Milik

Proses pembebanan Hak Tanggungan terhadap Hak Guna Bangunan yang telah dilakukan peningkatan menjadi Hak Milik, dibuat di hadapan Pejabat Pembuat Akta Tanah (PPAT), yang pelaksanaannya dilakukan melalui 2 (dua) tahap (Adrian Sutedi: 2012) yaitu:

a) Tahap pemberian Hak Tanggungan Pemberian Hak Tanggungan terhadap Hak yang telah dirubah menjadi Hak milik di lakukan di hadapan PPAT, biasanya kreditur dalam pembuatan akta Pemberian Hak Tanggungan, dibuat di hadapan PPAT yang sudah menjadi rekanannya dan PPAT yang menerima kuasa dari Debitur untuk permohonan Peningkatan Hak Guna Bangunan menjadi Hak Milik. Pembuatan akta pemberian Hak Tanggungan dibuat berdasarkan SKMHT yang telah diberikan oleh debitur kepada kreditur.

Pemberian Hak Tanggungan terhadap Jaminan Hak yang telah dirubah menjadi Hak Milik di hadapan Pejabat Pembuat Akta Tanah, wajib mencantumkan:

1) Nama pemegang hak dan identitasnya; domisili; penunjukan secara jelas utang-utang yang dijamin; nilai hak tanggungan; uraian tentang objek Hak Tanggungan;

2) Janji-Janji pemberi Hak Tanggungan kepada Penerima Hak Tanggungan sebagai mana tercantum dalam Undang-Undang Hak tanggungan Nomor 4 tahun 1996 Pasal 11 ayat (2)

Akta pemberian Hak Tanggungan yang dibuat dihadapan PPAT di buat sebanyak 2 lembar, lembar Pertama di simpan di Kantor PPAT sebagai Minuta, Lembar Kedua disampaikan kepada Kepala Kantor Pertanahan, untuk keperluan Pendaftaran Hak Tanggungan.

b) Tahap Pendaftaran Hak Tanggungan Untuk memperoleh kepastian mengenai kedudukan yang diutamakan bagi kreditur selaku pemegang Hak Tanggungan, Akta pemberian Hak Tanggungan yang sudah dibuat di hadapan PPAT, oleh PPAT berdasarkan Penjelasan atas Pasal 13 ayat (2) UUHT 
Aflinda Dewi: Peningkatan Hak Guna Bangunan Rumah Tinggal Dibebani Hak...

no.4 tahun 1996, yang menyatakan bahwa PPAT wajib melaksanakan pendaftaran Hak Tanggungan karena Jabatannya (ex Officio), kepada Kantor Pertanahan selambat-lambatnya 7 (tujuh) hari kerja setelah penandatangannya, untuk memenuhi asas Publisitas Hak Tanggungan (Adrian Sutedi, 2012) Pengiriman Akta Pemberian Hak Tanggungan pada Kantor Pertanahan setempat untuk didaftarkan, dikirim langsung oleh PPAT melalui petugasnya dengan melampirkan warkah-warkah lain yang diperlukan untuk pendaftaran Akta Pemberian Hak Tanggungan.

Dokumen-dokumen yang dikirim oleh PPAT kepada Kepala Kantor Pertanahan Kota Padang adalah sebagai berikut :

a) Surat Pengantar dari PPAT

b) Surat permohonan pendaftaran Hak Tanggungan dari PPAT (selaku kuasa dari kreditor penerima Hak Tanggungan).

c) Fotocopy KTP pemberi dan penerima Hak Tanggungan (yang dilegalisir oleh Notaris).

d) Sertifikat Hak Milik (hasil perubahan Hak Guna Bangunan yang telah dibubuhi catatan kesesuaiannya dengan data yang ada di Kantor Pertanahan).

e) Lembar kedua APHT

f) Salinan APHT yang sudah di paraf oleh PPAT, untuk keperluan lampiran Sertipikat Hak Tanggungan yang diterbitkan oleh Kantor Pertanahan Kota Padang. g) Surat Kuasa Membebankan Hak Tanggungan (SKMHT).

h) Surat Kuasa pengurusan dari kreditor pemegang Hak Tanggungan kepada petugas /Pegawai PPAT yang diketahui oleh PPAT.

i) SPPT PBB tahun berjalan atas Objek Hak Tanggungan.

j) Menyetor Pendapatan Negara Bukan Pajak (PNBP) sebesar Rp.50.000.-

Atas dasar data yang tercantum dalam Akta Pemberian Hak Tanggungan, Kepala Kantor Pertanahan mendaftarkan APHT tersebut dengan membuatkan buku tanah Hak Tanggungan serta mencatat pada buku tanah dan pada Sertipikat Hak Milik hasil peningkatan yang menjadi objek Hak Tanggungan.

Hak Tanggungan atas Hak milik hasil peningkatan tersebut, akan lahir tanggal pada hari ketujuh setelah penerimaan secara lengkap dokumen-dokumen yang diperlukan untuk pendaftaran Hak Tanggungan, dan jika hari ketujuh itu jatuh pada hari libur, buku tanah yang bersangkutan diberi tanggal pada hari berikutnya atau pada hari kerja. Sertipikat Hak Tanggungan terdiri dari Salinan buku tanah Hak Tanggungan dan salinan Akta Pemberian Hak Tanggungan yang telah ditandatangani oleh Kepala Kantor Pertanahan, yang kemudian dijahitkan menjadi satu dalam bentuk buku sertipikat Hak Tanggungan.

\section{SIMPULAN}

Dari uraian yang peneliti tulis diatas, dan hasil dari penelitian di lapangan, 
dapat disimpulkan hasil penelitian sebagai berikut :

1. Hak Guna Bangunan yang Rumah Tinggal yang dibebani Hak Tanggungan dapat dimohonkan Peningkatan Hak milik oleh Debitur, tanpa melunasi hutangnya terlebih dahulu pada kreditur. Hal tersebut dapatdilakukanberdasarkan

Peraturan Menteri Negara Agraria/Kepala Badan Pertanahan Nasional Nomor 5 Tahun 1998 tentang perubahan Hak Guna Bangunan atau Hak Pakai atas tanah untuk rumah tinggal yang dibebani Hak Tanggungan menjadi Hak Milik serta Surat Edaran Menteri Negara Agraria Nomor 110-2666 Tahun 1998. Permohonan Peningkatan Hak Guna Bangunan yang dibebani Hak Tanggungan menjadi Hak Milik dapat dilaksanakan berdasarkan Surat Persetujuan yang diberikan oleh Kreditor kepada Debitur. Untuk kelangsungan Jaminan kredit, sebelum peningkatan Hak Milik dimohonkan Debitor memberikan Surat Kuasa Membebankan Hak Tanggungan (SKMHT) kepada Kreditor.

2. Penghapusan Hak Tanggungan yang dibebankan kepada Hak Guna Bangunan untuk kepentingan Peningkatan Hak, dilakukan oleh Kepala Kantor Pertanahan karena Jabatannya, bersamaan dengan pendaftaran Peningkatan Hak Guna Bangunan yang dibebani Hak Tanggungan menjadi Hak Milik.
3. Pembebanan Hak Tanggungan atas Hak Milik hasil perubahan dibuat dihadapan Pejabat Pembuat Akta Tanah oleh Kreditur berdasarkan Surat Kuasa Membebankan Hak

Tanggungan (SKMHT) yang diberikan oleh Debitur kepada Kreditur sebelum Peningkatan Hak milik, dan selambat-lambatnya 7 (tujuh) hari setelah pemberian Hak Tangggungan harus dikirim oleh Pejabat Pembuat Akta Tanah melalui petugasnya ke kantor Pertanahan setempat.

\section{DAFTAR PUSTAKA}

\section{Buku :}

Adrian Sutedi, 2012. Hukum Hak Tanggungan, PT.Sinar Grafika, Jakarta.

A.P. Parlindungan,1999, Pendaftaran Tanah Indonesia, Mandar Maju Bandung.

Urip Santoso, 2012, Hukum Agraria Kajian Komprehensif, edisi pertama, Kencana Grup, Jakarta.

Jurnal :

H.M Arba; Arif Rahman; Muhammad Umar; Wiwiek Wahyuningsih; Shinta Andriyani. 2016. Implikasi Hukum Peningkatan Status Hak Guna Bangunan (HGB) dan Hak Pakai (HP) Atas Rumah Tinggal Objek Terhadap Kreditur. Jurnal Hukum Jatiswara. Vol 31, No 1, (2016).

Tommy Surya Atmaja, Hambatan Dalam Pelaksanaan Peningkatan Hak Guna Bangunan menjadi Hak Milik ata Kepemilikan Rumah Pada 
Aflinda Dewi: Peningkatan Hak Guna Bangunan Rumah Tinggal Dibebani Hak...

Perumnas I di Kota Pontianak. E.Jurnal Gloria Yuris.Vol.2 Nomor 3 (2014).

Rachasetia Isneni Hakim; Yani Pujiwati; Betty Rabiati: 2008, Hak Prioritas dalam Perolehan Tanah Hak Guna Bangunan Yang habis Jangka Waktunya di Tinjau dari UndangUndang Nomor 5 tahun 1960 Tentang Peraturan Dasar-Dasar Pokok Agraria Dan Keputusan Menteri Negara Agraria/Kepala Badan Pertanahan Nasional Nmor 6 tahun 1998 Tentang Pemberian Hak Milik Tanah Untuk Rumah Tinggal. Acta Jurnal.Issn:26143542 Eissn :2614-3550

Ade Fitriawan Sayuti, 2012, Hambatan Dalam Pelaksanaan Peningkatan Hak Guna Bangunan (HGB) Menjadi Hak Milik (HM) Untuk Rumah Tinggal Yang Dibebani Hak Tanggungan (Studi di Kota Balikpapan). Student Jurnal
Hendri Budiyanto; Noor Septanti; Muhammad Najib Imamullah, Pembebanan Hak Tangggungan terhadap Hak Guna Bangunan Dalam Perubahan Status Menjadi Hak Milik. Jurnal Repertorium. Volume 3; 2015

WD Sukirno; 2004, Impelementasi Regulasi Tentang Peningkatan Hak Guna Bangunan (HGB) Menjadi Hak Milik (HM) Untuk Rumah Tinggal Di Kota Semarang. Jurnal

Hukum

Diponegoro. Np2, April 2014

Volume 3,

Setyaningih, Anis Mashdurohatun; Peranan Notaris Dalam Pembuatan akta Pemberian Hak Tanggungan Terhadap Perjanjian Kredit Antara Kreditur dan

Debitur Dengan Jaminan Hak Tanggungan Di Purwokerta. Jurnal Akta, Volume 5 Nomor 1 Maret 2018. 